\title{
CAN MACROSOMIC FETUSES BE DELIVERED AT 38 WEEKS OF GESTATION?
}

\author{
Makrozomik Fetuslar 38. Gebelik Haftasında Doğurtulabilir Mi?
}

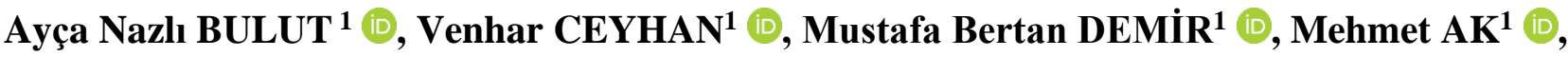 \\ Emine AYDIN ${ }^{2} \mathbb{D}$, Mehmet DOLANBAY $^{3}$
}

\author{
${ }^{l}$ Department of Obstetrics and Gynecology, Kayseri City Education and Research Hospital, KAYSERİ, TÜRKIYE \\ ${ }^{2}$ Department of Obstetrics and Gynecology, Istanbul Medipol University, ISTANBUL, TÜRKIYE \\ ${ }^{3}$ Department of Obstetrics and Gynecology, Erciyes University, Faculty of Medicine, KAYSERİ, TÜRKIYE
} \begin{abstract}
Objective: Numerous articles have been written on macrosomic fetuses, including the American College of Obstetricians and Gynecologists practice bulletin. However, there is no clear consensus about the time of birth. The aim of this study was to compare the maternal and fetal outcomes of women giving birth at $38^{+0}-38^{+6}$ weeks and those with deliveries at $\geq 39$ weeks in pregnancies complicated by fetal macrosomia, and to determine the effect on morbidity and mortality of delivery in the 38th gestational week.
\end{abstract}

Material and Methods: Data of women and their infants born in Kayseri Training and Research Hospital between 01 May 2018 and 31 March 2020 were analyzed retrospectively. The patients included were those with a singleton pregnancy delivered at $\geq 38$ weeks with a birthweight of $\geq 4000$ gr. Demographic data and medical history and birth outcomes of the patients were recorded from the hospital data system. Multiple pregnancies, those with fetal anomalies and births <38 weeks were excluded from the study. The patients were separated into two groups as those who gave birth at $38^{+0}-38^{+6}$ gestational weeks (Group 1) and those who gave birth at $\geq 39$ weeks (Group 2).

Results: Maternal and/or fetal trauma was found to be statistically significantly higher in nulliparous women with vaginal delivery $\geq 39$ weeks compared to those with vaginal delivery at $38^{+0}-38^{+6}$ weeks $(\mathrm{p}=0.017)$. No significant difference was observed between the groups in respect of fetal morbidity and mortality.

Conclusion: When fetal macrosomia is determined antenatally, rates of fetal and/or maternal trauma can be reduced with delivery planned for the 38th week without increasing fetal morbidity and mortality.

Keywords: Macrosomia, trauma, LGA, dystocia

\section{ÖZ}

Amaç: Makrozomik fetüsler hakkında, Amerikan Obstetrik ve Jinekoloji Derneğinin bültenleri de dahil olmak üzere çok sayıda makale yazılmıştır. Ancak doğum zamanı konusunda net bir fikir birliği yoktur. Bu çalışmanın amacı fetal makrozomi ile komplike gebeliklerde $38^{+0}-38^{+6}$ hafta arasında doğum yapan kadınlar ile $\geq 39$ hafta sonrasında doğum yapan kadınların maternal ve fetal sonuçlarını karşılaştırmak ve doğum haftasının 38. haftaya çekilmesinin yenidoğanın morbidite ve mortalitesini etkileme düzeyini belirlemektir.

Gereç ve Yöntemler: Bu retrospektif çalışmada, 01 Mayıs 2018-31 Mart 2020 tarihleri arasında Kayseri Eğitim ve Araştırma Hastanesinde doğum yapan kadınların ve bebeklerinin verileri geriye dönük olarak tarand1. Doğum ağırlığ $1 \geq 4000$ gram, tekil, $\geq 38$ hafta üzerinde doğum yapan hastalar çalışmaya dâhil edildi. Hastaların demografik ve medikal öyküleri ve doğum sonuçları hastane veri sisteminden kayıt edildi. Çoğul gebelikler, fetal anomaliler ve $<38$ gebelik haftasındaki doğumlar çalışma haricinde tutuldu. Hastalar $38^{+0-} 38^{+6}$ hafta arasında doğum yapanlar (Grup 1) ve $\geq 39$ haftada doğum yapanlar (Grup 2) olarak iki gruba ayrıldı.

Bulgular: $\geq 39$ haftadan sonra vajinal doğum yapan (grup 2) nullipar kadınlarda maternal veya fetal travma $38^{+0}-38^{+6}$ (grup 1) hafta arasında vajinal doğum yapan nullipar kadınlara oranla istatistiksel anlamlı olarak yüksek bulundu $(\mathrm{p}=0.017)$. İki grup arasında fetal morbidite ve mortalite incelendiğinde gruplar arasında anlamlı farklılık izlenmedi.

Sonuç: Doğum öncesi değerlendirmede fetal makrozomi saptanan gebelerde fetal ve/veya maternal travma oranları, fetal morbidite ve mortalite arttırılmadan 38. haftada planlanacak bir doğum ile azaltılabilir.

Anahtar Kelimeler: Makrozomi, travma, LGA, distosi

$\begin{array}{lc}\text { Correspondence / Yazışma Adresi: } & \text { Dr. Ayca Nazli BULUT } \\ \text { Kayseri City Education and Research Hospital, Department of Obstetrics and Gynecology, KAYSERİ, TÜRKIYYE } \\ \text { Phone / Tel: +90 505 6251433 } & \text { E-mail / E-posta: dr.nazlibulut@ gmail.com } \\ \text { Received / Geliş Tarihi: 09.01.2021 } & \text { Accepted / Kabul Tarihi: 21.06.2021 }\end{array}$




\section{INTRODUCTION}

Fetal macrosomia is defined as birthweight of $>4000 \mathrm{gr}$ or $>4500 \mathrm{gr}$, and $>90$ th percentile for gestational week (1). The incidence of fetal macrosomia is $9 \%$, it shows variations between countries, and has been associated with several factors, primarily maternal obesity, maternal diabetes mellitus (DM), a history of macrosomic fetus and gestational week at birth (1-6). The clinical importance of fetal macrosomia includes the increased risk of caesarean delivery, outcomes of maternal and fetal trauma, increased endocrinological problems later in childhood, and stillbirth $(1,7,8)$

When there is suspected fetal macrosomia diagnosed with prenatal ultrasonography, clinical examination and maternal risk factors together, to prevent the fetus becoming bigger and to avoid the above-mentioned complications, various solutions are recommended such as bringing maternal DM under control, lifestyle changes, diet and physical activity. However, despite these recommendations, there is still no clear consensus on the gestational week at which the fetus should be delivered $(1,9,10)$.

The aim of this study was to compare the maternal and fetal outcomes of women giving birth at $38^{+0}-38^{+6}$ weeks and those with deliveries at $\geq 39$ weeks in pregnancies complicated by fetal macrosomia, and to determine the effect on infant morbidity and mortality of delivery in the 38th gestational week.

\section{MATERIALS AND METHODS}

The data of women and their infants were analyzed retrospectively between 01 May 2018 and 31 March 2020. Approval for the study was granted by the Ethics Committee of Erciyes University (Erciyes University Clinical Research Ethics Committee, date: 25.12.2019, issue number: 2019/886). All procedures were made in compliance with the principles of the Helsinki Declaration.
The study included women with a single pregnancy of $\geq 38$ weeks with infant birthweight $\geq 4000$ gr. The patients were separated into two groups as those who gave birth at $38^{+0}-38^{+6}$ gestational weeks (Group 1) and those who gave birth at $\geq 39$ weeks (Group 2).

The groups were compared in respect of demographic data, obstetric and additional chronic disease history, the results of the oral glucose tolerance test performed at 24-28 gestational weeks, pre-pregnancy diabetic status, smoking status, maternal complications (deep vaginal tear, obstetric anal sphincter damage, bladder and urethra damage, uterine atonia, placenta retention, placenta detachment, uterine rupture), and fetal complications (shoulder dystocia, asphyxia, clavicle or humerus fracture, brachial nerve paralysis, the need for neonatal intensive care, meconium aspiration syndrome, respiratory distress syndrome (RDS), fetal loss during labour).

To evaluate the morbidity and mortality of the newborns, the hospital data recording system was scanned for the Apgar scores and the hemoglobin and bilirubin values of the infants in the first 24 hours. Gestational DM was defined according to the standards of the American College of Obstetricians and Gynecologists (ACOG). Gestational age at birth was defined according to correlation made to the last menstrual date or the fetal crown-rump distance on first trimester ultrasonography, if available. All these parameters were compared between the two groups. Patients with multiple pregnancies, fetal anomalies or delivery <38 weeks were excluded from the study.

\section{Statistical Analysis}

Data obtained in the study were analyzed statistically using SPSS version 25.0 (IBM Corporation, Armonk, NY, USA) software. Categorical data were stated as number (n) and percentage (\%), and continuous data as mean \pm standard deviation (SD), or median, minimum and maximum values. In the comparisons of categorical variables, the Chi-square test or the Fisher exact test statistic were used. In the comparisons of 
continuous measurements between the groups, the Student's t-test was applied to data showing normal distribution, and the Mann Whitney U-test to data not showing normal distribution. Logistic regression analysis was performed to determine independent risk factors that have had influence on macrosomia. A value of $p<0.05$ was accepted as statistically significant in all the tests.

\section{RESULTS}

The study included 689 women with a birth weight of $\geq 4000$ grams and a singleton pregnancy $>38$ weeks.

\section{Demographic Data}

The mean age of the patients included in the study was $28.3 \pm 9.2$ years. Group 1 comprised 208 (30.2\%) patients who gave birth at $38^{+0}-38^{+6}$ weeks, and group 2 comprised $481(69.8 \%)$ patients who gave birth at $\geq 39$ weeks. No significant difference was determined between the groups in respect of the type of birth as normal vaginal route or caesarean section $(\mathrm{C} / \mathrm{S})$ delivery. $\mathrm{C} / \mathrm{S}$ requirement was lower in group 1 but not statistically significant. The demographic data of the patients are shown in Table 1. Gestational DM was $8.7 \%$ in the group born between $38^{+0}-38^{+6}$ weeks and $9.1 \%$ in the group born at $\geq 39$ weeks. Type II diabetes rate was $4.8 \%$ in the group 1 and $1.5 \%$ in the group 2 (Table 1). This result was statistically significant $(\mathrm{p}=0.034)$. The causes of delivery in pregnant women who delivered between $38^{+0}-38^{+6}$ weeks were rupture of membranes $16.82 \% \quad(\mathrm{n}=35)$, preeclampsia $12.01 \%$ $(\mathrm{n}=25)$, spontaneous labor $33.65 \% \quad(\mathrm{n}=70)$, cord prolapse was $2.40 \%(n=5)$ and the previous cesarean section rate was $35.09 \%(\mathrm{n}=73)$.

Table 1: Demographic data of patients and comparative data of groups

\begin{tabular}{|c|c|c|c|c|c|c|c|c|}
\hline & \multicolumn{2}{|c|}{ All Patients $(n=689)$} & \multicolumn{2}{|c|}{$\begin{array}{c}38^{+0}-38^{+6} \text { Week } \\
(\text { Group 1) }(n=208)\end{array}$} & \multicolumn{2}{|c|}{$\begin{array}{l}\geq 39 \text { Week (Group 2) } \\
\qquad(\mathrm{n}=481)\end{array}$} & \multirow[t]{2}{*}{$\mathbf{P}$} & \multirow[t]{2}{*}{$\begin{array}{l}\text { OddsRatio } \\
(95 \% \mathrm{CI})\end{array}$} \\
\hline & Mean \pm SD & $\mathrm{n}(\%)$ & Mean \pm SD & $\mathrm{n}(\%)$ & Mean \pm SD & $\mathrm{n}(\%)$ & & \\
\hline Age (year) & $28.3 \pm 9.2$ & & $28.2 \pm 6.7$ & & $27.9 \pm 5.6$ & & 0.477 & \\
\hline Gravida & $2.9 \pm 1.6$ & & $3(1-11)$ & & $3(1-10)$ & & 0.446 & \\
\hline Parity & $2.7 \pm 1.5$ & & $3(0-9)$ & & $2(0-10)$ & & 0.225 & \\
\hline Gestational week & $39.4 \pm 0.9$ & & $38.4 \pm 0.2$ & & $39.9 \pm 0.8$ & & 0.0001 & \\
\hline Maternal BMI $\left(\mathrm{kg} / \mathrm{m}^{2}\right.$ & $31.7 \pm 7.1$ & & $31.8 \pm 5.0$ & & $31.6 \pm 7.9$ & & 0.788 & \\
\hline Infant weight (gr) & $4208.9 \pm 215.9$ & & $4192.0 \pm 224.4$ & & $4216.3 \pm 212$ & & 0.176 & \\
\hline \multicolumn{9}{|c|}{ Diabetes Melitus (DM) } \\
\hline Gestationel DM & & $62(9.0)$ & & $18(8.7)$ & & $44(9.1)$ & 0.034 & $3.4(1.3-9.1)$ \\
\hline Type II DM & & $17(2.5)$ & & $10(4.8)$ & & $7(1.5)$ & & $3.5(1.2-10.6)$ \\
\hline Smoking & & $7(1.0)$ & & $1(0.5)$ & & $6(1.2)$ & 0.681 & \\
\hline APGAR 1.dk & $7.9 \pm 0.9$ & & $7.9 \pm 1.0$ & & $8.0 \pm 0.9$ & & 0.370 & \\
\hline APGAR 5.dk & $9.2 \pm 0.7$ & & $9.2 \pm 0.8$ & & $9.3 \pm 0.7$ & & 0.982 & \\
\hline Induction of labour & & $102(14.8)$ & & $40(19.23)$ & & $82(17.04)$ & & 1.000 \\
\hline Vaginal delivery & & $408(59.2)$ & & $121(58.2)$ & & $287(59.9)$ & & 0.674 \\
\hline Cesarean delivery & & $281(40.8)$ & & $87(41.8)$ & & 194(40.1) & & 0.094 \\
\hline
\end{tabular}

BMI: body mass index, DM: diabetes mellitus 
In total, 102 patients (14.8\%) received labor induction. The causes of induction of these patients were rupture of membranes $(58.82 \%, \mathrm{n}=60)$, preeclampsia $(21.56 \%$, $\mathrm{n}=22)$ and DM (19.60\%, n=20). Complications in these patients were placental retention $(1.96 \%, \mathrm{n}=2 / 102)$, shoulder dystocia $(2.94 \%, \mathrm{n}=3 / 102)$, and deep vaginal laceration $(2.94 \%, \mathrm{n}=3 / 102)$.

When all the births were analyzed, maternal and fetal complications were seen at a higher rate in the cases with the infant born at $\geq 39$ weeks but the difference was not statistically significant. After removal of the multiparous women, the rate of maternal and fetal trauma in the nulliparous women in the group who gave birth at $\geq 39$ weeks was seen to be statistically significantly high $(0 / 30 \quad(0 \%)$ vs. $8 / 41 \quad(19.5 \%)$ $\mathrm{p}=0.017$ ) (Tables 2, 3). No statistically significant difference was determined between the groups in respect of complications that can develop associated with early birth such as the requirement for neonatal intensive care, RDS development, intraventricular hemorrhage and necrotizing enterocolitis (Table 3 ).

No statistically significant difference was determined between the groups in respect of complications that can develop associated with early birth such as the requirement for neonatal intensive care, RDS development, intraventricular hemorrhage and necrotizing enterocolitis (Table 3).

Table 2: Comparision of maternal complications

\begin{tabular}{|c|c|c|c|c|}
\hline & $\begin{array}{l}\text { All Patients } \\
\quad(n=689)\end{array}$ & 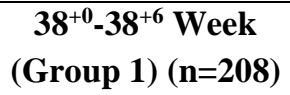 & $\begin{array}{c}\geq 39 \text { week } \\
(\text { Group } 2)(n=481)\end{array}$ & $\mathbf{p}$ \\
\hline & $\mathrm{N}(\%)$ & $\mathrm{N}(\%)$ & $\mathrm{N}(\%)$ & \\
\hline Deep vaginal laseration & $8(1.2)$ & $2(1.0)$ & $6(1.3)$ & 1.000 \\
\hline Obstetric anal sphincter injury & $4(0.6)$ & $0(0)$ & $4(0.8)$ & 0.321 \\
\hline Bladder and urethra injury & $0(0)$ & $0(0)$ & $0(0)$ & \\
\hline Placenta retention & $4(0.6)$ & $2(1.0)$ & $2(0.4)$ & 0.588 \\
\hline Uterine atony & $14(2.0)$ & $4(1.9)$ & $10(2.1)$ & 1.000 \\
\hline Ablation placenta & $1(0.1)$ & $0(0)$ & $1(0.2)$ & 1.000 \\
\hline Uterine rupture & $0(0)$ & $0(0)$ & $0(0)$ & \\
\hline
\end{tabular}

Table 3: Comparision of fetal complications

\begin{tabular}{|c|c|c|c|c|}
\hline & $\begin{array}{c}\text { All Patients } \\
(\mathrm{n}=689)\end{array}$ & $\begin{array}{c}38^{+0}-38^{+6} \text { week } \\
\text { (Group 1) }(n=208)\end{array}$ & $\begin{array}{c}\geq 39 \text { week } \\
(\text { Group } 2)(n=481)\end{array}$ & $\mathbf{p}$ \\
\hline & $\mathrm{n}(\%)$ & $\mathrm{n}(\%)$ & $\mathrm{n}(\%)$ & \\
\hline Clavicula fracture & $5(0.7)$ & $1(0.5)$ & $4(0.8)$ & 1.000 \\
\hline Humerous fracture & $0(0)$ & $0(0)$ & $0(0)$ & \\
\hline Brachial plexus injury & $2(0.3)$ & $0(0)$ & $2(0.4)$ & 1.000 \\
\hline Shoulder dystocia & $5(0.7)$ & $0(0)$ & $5(1.0)$ & 0.330 \\
\hline Cephal hematoma & $4(0.6)$ & $0(0)$ & $4(0.8)$ & 0.321 \\
\hline Asphyxia & $6(0.8)$ & $1(0.5)$ & $5(1.0)$ & 0.674 \\
\hline Pneumonia & $1(0.14)$ & $0(0)$ & $1(0.2)$ & 1.000 \\
\hline Meconium aspiration & $4(0.6)$ & $0(0)$ & $4(0.8)$ & 0.321 \\
\hline Stillbirth & $4(0.6)$ & $2(1.0)$ & $2(0.4)$ & 0.588 \\
\hline Respiratuar distress syndrome & $9(1.3)$ & $4(1.92)$ & $5(1.03)$ & 1.000 \\
\hline Necrotisian enterocolit & $0(0)$ & $0(0)$ & $0(0)$ & \\
\hline Intraventricular bleeding & $0(0)$ & $0(0)$ & $0(0)$ & \\
\hline
\end{tabular}




\section{DISCUSSION}

When fetal macrosomia is determined, there are three options: (i) elective caesarean delivery, but this is recommended only when the estimated fetal weight is $\geq 4500 \mathrm{~g}$ for diabetic women and $5000 \mathrm{~g}$ for nondiabetic women; (ii) expectant management, but infants with birth weight $\geq 4500$ gr have a significantly increased risk of perinatal mortality, neonatal asphyxia, trauma, and cesarean delivery; (iii) induction of labour, thereby reducing the possibility of further fetal growth, and reducing the risk of cesarean delivery for cephalopelvic incompatibility and shoulder dystocia.

Induction in the early weeks is known to reduce the rates of caesarean delivery, maternal morbidity and complications and decrease shoulder dystocia and fetal trauma in labour. However, there are limited data related to the frequency of neonatal complications and morbidity in macrosomic fetuses induced at an early birth week.

In the current study it was aimed to determine the maternal and fetal outcomes of induced delivery of macrosomic fetuses after completion of 38 gestational weeks by comparing the maternal and fetal outcomes of macrosomic singleton pregnancies born at $38^{+0}-38^{+6}$ gestational weeks with those born at $\geq 39$ weeks.

The recommended approach throughout the world for non-diabetic pregnant patients with estimated fetal birthweight of $\geq 4500$ gr is elective caesarean delivery. In our study aiming to determine the benefits of induction of vaginal delivery before reaching the estimated birthweight of $4500 \mathrm{gr}$, for both mother and infant, the results showed that although not statistically significant, delivery in the 38th gestational week reduced the rate of maternal and fetal trauma, there was a lower rate of $\mathrm{C} / \mathrm{S}$ delivery because of macrosomic fetus and the need for neonatal intensive care and neonatal complications were reduced. Moreover, as no maternal and fetal trauma was observed in the nulliparous women giving birth in the 38th week, there was a statistically significant difference compared to those who gave birth at $\geq 39$ weeks ( $\mathrm{p}=0.017$ ). In this study type II diabetes rate was $4.8 \%$ in the 1 st group and $1.5 \%$ in the 2 nd group (Table 1). This result was statistically significant $(\mathrm{p}=0.034)$. This explains the fact that there are fewer diabetic pregnant women at $\geq 39$ weeks due to the fact that type II diabetic pregnant women had given birth at earlier weeks.

In the vast majority of previous studies, elective birth induction has been planned for the 39th gestational week, and when the results are compared, a much lower rate of maternal and fetal complications compared to the observation strategy has been observed (11). Although there are studies that have proposed that birth induction of macrosomic fetuses reduces maternal and fetal trauma compared to the watch-and-wait strategy, ACOG does not recommend induction because of macrosomia, stating that birth induction does not improve maternal and fetal outcomes (1). According to the results of the current study, induction was applied to $18.3 \%$ of the patients, and there was a statistically significantly higher rate of vaginal delivery in the women with birth induction $(\mathrm{p}=0.026)$. The most common indication for $\mathrm{C} / \mathrm{S}$ delivery in these women was stalled labour/failed induction $(\mathrm{p}=0.0001)$. However, the rate of $\mathrm{C} / \mathrm{S}$ delivery because of macrosomic fetus was observed to be significantly higher in patients who were not induced $(\mathrm{p}=0.001)$.

It is known that macrosomic fetuses, defined as birthweight $>4000$ gr or $>4500$ gr, are exposed to more birth trauma, and similarly there is an increased risk of birth trauma for the mother, and this is affected by gestational age, birth weight and macrosomia risk (1). According to the current study results, although not statistically significant, the birthweight of infants born at $38^{+0}-38^{+6}$ weeks was observed to be lower than that of those born at $\geq 39$ weeks $(p=0.176)$. This supports the fact that as the gestational week increases, so the infant weight increases (1,8-10). 
It has been reported in literature that clavicular fracture is seen in approximately $0.4 \%-0.6 \%$ of all births and generally heals without any sequelae, but the incidence of clavicular fracture in a macrosomic fetus increases 10-fold (1). In the current study, clavicular fracture was determined at the rate of $0.7 \%$ in the study group formed of all the macrosomic fetuses. Brachial plexus injury has been determined at the rate of approximately $1.5 \%$ in births in the USA, and this rate has been reported to be $2.6 \%-7 \%$ in vaginal births. When infant birthweight is $>4500 \mathrm{gr}$, this risk is increased 18-21fold (1). In the current study, the rate of brachial plexus injury was determined as $0.3 \%$, and the rate was similar in patients with vaginal birth and those who underwent $\mathrm{C} / \mathrm{S}$ delivery because of macrosomic fetus $(p=0.329)$. The incidence of shoulder dystocia is not clearly known as it has not been well documented but the incidence has been reported as $0.2 \%-3 \%$ (12). In the current study, shoulder dystocia was determined at the rate of $0.7 \%$.

If there is no medical indication, American Academy of Pediatrics does not recommend birth before 39 gestational weeks because of macrosomia to reduce neonatal complications (1). However, the results of the current study showed a reduction, although not statistically significant, in birth trauma and the need for neonatal intensive care in infants born in the 38th gestational week compared to those born $\geq 39$ weeks, especially in nulliparous women. The neonatal complications of the infants born at 38-39 weeks were not greater in any infant compared to those born at \pm 39 weeks. Therefore, based on the results of this study, it can be suggested that macrosomic fetuses can be delivered in the 38th gestational week as they are not greatly affected by maternal and fetal trauma, and birth in these weeks does not put the infant at risk of neonatal complications. Just as multiparity is a factor, so birth induction is also a factor affecting normal birth. It is clear that each birth will be easier and quicker than the previous one, and maternal and fetal trauma will decrease. This is also valid for macrosomic fetuses. When the factors of multiparity and induction were removed from the current study analysis, no maternal or fetal trauma was observed in the nulliparous patient group who gave birth at $38^{+0}-38^{+6}$ gestational weeks and this rate was determined as $19.5 \%$ in those who gave birth at $\geq 39$ weeks $(p=0.017)$. Based on this result, as there was no difference in Apgar scores and the need for neonatal intensive care, birth in the 38th gestational week for women with a suspected macrosomic fetus, especially for nulliparous women, can be considered as an appropriate approach to reduce maternal trauma.

One of the limitations of the study is that it was conducted retrospectively. In addition, the study did not compare nulliparas with multiparas. In the study, only the effect of the difference between gestational weeks on birth trauma was examined.

In conclusion, the results of this study showed that maternal trauma in nulliparous women giving birth in the 38th gestational week was significantly lower than that of women who gave birth $\geq 39$ weeks. However, it must be said that a definitive diagnosis of fetal macrosomia can only be made by weighing the infant at birth. When there is a suspicion of fetal macrosomia supported by maternal demographic characteristics, clinical examination and ultrasonographic measurements, with lifestyle changes before further gestational weeks and earlier delivery with induction, birth in the 38th gestational week can be recommended.

Conflict of Interest: The authors certify that they have no affiliations with or involvement any organization or entity with any financial interest (such as honoraria; educational grants; participation in speakers' bureaus; membership, employment, consultancies, stock ownership, or other equity interest; and expert testimony or patent-licensing arrangements), or nonfinancial interest (such as personal or professional 
relationships, affiliations, knowledge or beliefs) in the subject matter or materials discussed in this manuscript.

\section{Support and Acknowledgment: None}

Researchers' Contribution Rate Statement: Concept/Design: ANB; Analysis/Interpretation: VC, MBD, MA; Data Collection: VC, MBD, MA; Writer: ANB; EA Critical Review: ANB, EA, MD; Supervision: EA, MD.

Ethics Committe Aproval: Erciyes University Clinical Research Ethics Committee, date:25.12.2019, issue number: 2019/886.

\section{REFERENCES}

1. Macrosomia: ACOG Practice Bulletin, Number 216. Obstet Gynecol. 2020;135(1):18-35.

2. American College of Obstetricians and Gynecologists' Committee on Practice BulletinsObstetrics. Practice Bulletin No. 173: Fetal Macrosomia. Obstet Gynecol. 2016;128(5):195209.

3. Chauhan SP, Grobman WA, Gherman RA, Chauhan VB, Chang G, Magann EF et al. Suspicion and treatment of the macrosomic fetus: a review. Am J Obstet Gynecol. 2005;193:332-46.

4. Martin JA, Hamilton BE, Osterman MJK, Driscoll AK, Drake P. Births: Final Data for 2017. Natl Vital Stat Rep. 2018;67(8):1-50.

5. Li G, Kong L, Li Z, Zhang L, Fan L, Zou L et al. Prevalence of macrosomia and its risk Factors in China: A multicentre survey based on birth data involving 101723 singleton term infants. Paediatr Perinat Epidemiol. 2014;28(4):345-50.

6. Koyanagi A, Zhang J, Dagvadorj A, Hirayama F, Shibuya K, Souza JP et al. Macrosomia in 23 developing countries: an analysis of a multicountry, facility-based, cross-sectional survey. Lancet. 2013;381(9665):476-83.
7. Zhu Y, Olsen SF, Mendola P, Yeung EH, Vaag A, Bowers $\mathrm{K}$ et al. Growth and obesity through the first $7 \mathrm{y}$ of life in association with levels of maternal glycemia during pregnancy: a prospective cohort study. Am J Clin Nutr. 2016;103(3):794800.

8. Glodean DM, Miclea D, Popa AR. Macrosomia. A systematic review of recent literature. Rom $\mathrm{J}$ Diabetes Nutr Metab Dis. 2018;25(2):187-95.

9. Araujo Júnior E, Peixoto AB, Zamarian ACP, Elito Júnior J, Tonni G. Macrosomia. Best Pract Res Clin Obstet Gynaecol. 2017;38:83-96.

10. Stotland NE, Caughey AB, Breed EM, Escobar GJ. Risk factors and obstetric complications associated with macrosomia. Int $\mathbf{J}$ Gynaecol Obstet. 2004;87(3):220-6.

11. Sinkey RG, Blanchard CT, Szychowski JM, Ausbeck E, Subramaniam A, Neely CL et al. Elective induction of labor in the 39th week of gestation compared with expectant management of low-risk multiparous women. Obstet Gynecol. 2019;134(2):282-7.

12. Sancetta R, Khanzada H, Leante R. Shoulder shrug maneuver to facilitate delivery during shoulder dystocia. Obstet Gynecol. 2019;133(6):1178-81. 